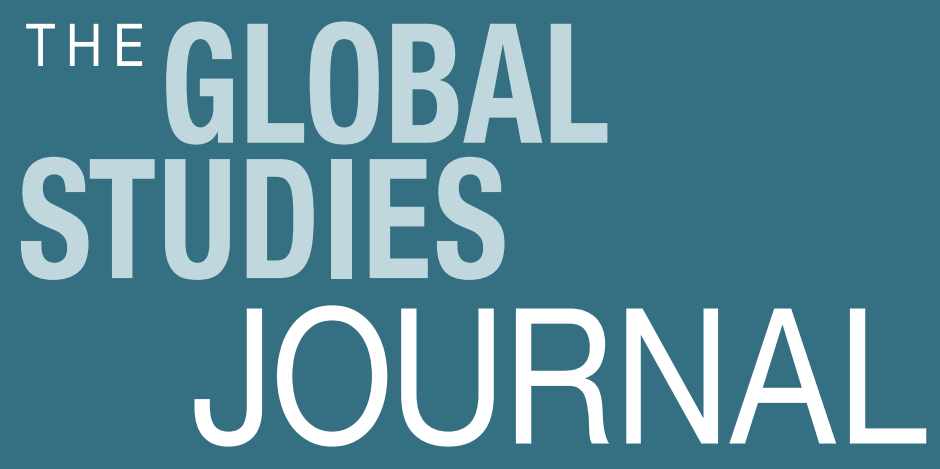

Volume 3, Number 2

Globalisation and China's Military Modernisation: Fear not China

Xiaoli Jiang and Yihong Gong 
THE GLOBAL STUDIES JOURNAL

http://www.globalstudiesjournal.com/

First published in 2010 in Champaign, Illinois, USA by Common Ground Publishing LLC www.CommonGroundPublishing.com.

(C) 2010 (individual papers), the author(s)

(C) 2010 (selection and editorial matter) Common Ground

Authors are responsible for the accuracy of citations, quotations, diagrams, tables and maps.

All rights reserved. Apart from fair use for the purposes of study, research, criticism or review as permitted under the Copyright Act (Australia), no part of this work may be reproduced without written permission from the publisher. For permissions and other inquiries, please contact

<cg-support@ commongroundpublishing.com>.

ISSN: $1835-4432$

Publisher Site: http://www.globalstudies-journal.com/

THE GLOBAL STUDIES JOURNAL is peer-reviewed, supported by rigorous processes of criterion-referenced article ranking and qualitative commentary, ensuring that only intellectual work of the greatest substance and highest significance is published.

Typeset in Common Ground Markup Language using CGCreator multichannel typesetting system

http://www.commongroundpublishing.com/software/ 


\title{
Globalisation and China's Military Modernisation: Fear not China
}

\author{
Xiaoli Jiang, University of Ballarat, Victoria, Australia \\ Yihong Gong, Baiyun University, Guangdong, China
}

\begin{abstract}
China has one of the most powerful military forces in the world. However, a little over 100 years ago, the Chinese military was repeatedly defeated by Western colonial powers and Japan. These defeats motivated the Chinese to make dramatic changes to their military forces. Based on an analysis of contemporary Chinese history and cultural values, it would appear there have been four major attempts to modernise the Chinese military. These attempts have been consistently driven by the need to defend Chinese national interests and self-esteem. Although the current military's rapid transformation has alarmed the West, in reality China's intentions are more about self-defence and nullifying internal independence movements, in particular Taiwan, and has little to do with expansion of territory.
\end{abstract}

Keywords: Globalisation, China, Military, Modernisation

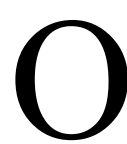

CTOBER $1^{\text {st }} 2009$ was the $60^{\text {th }}$ anniversary of the People's Republic of China. It was marked by a military parade showcasing what the Chinese perceived as their military modernisation. According to foreign commentators, themes of the military parade included information warfare and the creation of a smaller, more professional military force (Friedman. 2009). China is perceived as having one of the most powerful military forces in the world (Fisher, 2008).

However, a little over 100 years ago, China's military was repeatedly defeated by Western colonial powers and Japan. Chinese today view that part of their history as a chapter in humiliation and shame. These defeats were a major motivational factor for China's numerous attempts to modernize its military.

This paper identifies four attempts by the Chinese military to modernise its forces in a world of globalisation. Through an historical account of struggles with international invasions and threats to Chinese sovereignty the paper reveals the major motivations of the modernisation efforts. It also explores the cultural roots that underpin changes to the Chinese military designed to meet the challenges of globalisation.

\section{The Early Development of China's Military in the Context of a Negative Global Environment}

Gunpowder was invented by the Chinese in the Jin Dynasty (1115-1234) and guns were widely available to its military forces during the mid-fourteenth century. For example, guns were placed along the Great Wall to enhance its defensive strength. China's Admiral Zhenghe's seven voyages between 1405 and 1433 to South and Southeast Asia used fleets armed with guns. At that time the Chinese possessed impressive oceangoing as well as riverbound ships. However, due to government restrictions not to allow the knowledge of gun

The Global Studies Journal

C $O M M O N$

Volume 3, Number 2, 2010, http://www.globalstudiesjournal.com/, ISSN 1835-4432

C Common Ground, Xiaoli Jiang, Yihong Gong, All Rights Reserved, Permissions:

cg-support@commongroundpublishing.com 
and gunpowder making outside of the military, there was a lack of progress in Chinese gun technology in the Ming (1368-1644) and Qing (1644-1911) dynasties. By mid $17^{\text {th }}$ century foreign firearms had become superior as did European naval vessels (Lorge, 2008).

By the late $18^{\text {th }}$ and early $19^{\text {th }}$ century, the Chinese military continued to fall further behind Europe. The West's experiences of European centered wars and the associated evolution of modern weaponry, tactics and strategies compounded the Chinese military decline as did the industrial revolution and rapid globalisation. At the same time, the combined effect of the rebellions by the Miao, White Lotus and Eight Trigram weakened the Qing Dynasty (Elleman, 2001). The Opium War, according to some Western views (Elleman, 2001) was a trade war, and British traders won equal treatment through the war. However, the Chinese version of this event was that it was bullied and invaded by the British, backed up by its military power (Liu, 2007). Regardless of the interpretations of the war, the Qing military was based on the traditional Banner system. When compared to Western military it was weak. During the War, the most common weapons of the Qing soldier were swords, shields and pikes. China's naval defense force was small and confined to the Guangdong coast (Fay, 1975). Further, Chinese troops were underpaid and undereducated (Zarrow, 2005). Their defeat resulted in the signing of the Treaty of Nanking. Under the Treaty Hong Kong was ceded to Britain, five Chinese ports were opened to the British and a large amount of indemnity was paid to Britain. Further, land areas of 40,000 square miles between China and the British colony, India, were drawn into the border of India (Hoffmann, 1990). Today Chinese people believe one of the main reasons for the slow development of the Chinese military at the time was due to an inward looking view of the world by the Qing Court and a lack of desire to be integrated into a globalising world with its rapid technological development $(\mathrm{Ni}$, 2008).

However, Guandong was over $2000 \mathrm{kms}$ away from the administrative centre in Beijing. The defeat in the first Opium War did not change the ways the Qing Court saw the world and its practices. Following the first Opium War in 1840, China was defeated in the Arrow War in 1860, commonly called the Second Opium War by the Chinese, by the Anglo-French troops. The imperial Summer Palaces, architectural wonders of the world at the time were looted and torched during the war. Treaties were signed with Britain and France to open more ports and pay more indemnities. To many Chinese, it was heart-breaking to see the ruins of the palaces. For the Qing Court, its wealth was fast depleting. This time the shock of the defeat to the Chinese, especially within the Qing Court, was profound because the invaders came to Beijing, the capital. The Chinese people's sense of security was deeply eroded.

As a result, in 1861, the Chinese government started the Self -Strengthening Movement. The most important goal during the early phase of the movement was its first military modernisation. It set out to develop military industries, namely the construction of military arsenals and of shipbuilding dockyards to strengthen the Chinese navy. The government also purchased a large amount of military equipment including guns, cannons and warships from the West. Fortresses were also built at important coastal ports, all imitating the Western approach to defence (Tan, 2009). In 1870, China established its first modern naval force. By 1882 China had 50 steam warships, half imported and half self built (Elleman, 2001). Foreigners were employed to train the Chinese: significant progress was made. Given past foreign invasions came from the sea, the first military modernisation was concentrated on strengthening the navy aiming to defend China's coastlines more effectively (Tan, 2009). 


\section{The Second Modernisation of China's Military Forces in Response to Foreign Aggression}

Between 1860 and 1911, the Qing court rapidly declined, aided by internal rebellions and foreign invasions. Between 1871 and 1875 Russian invaded Xinjiang. It resulted in the Chinese paying 9 million rubles as an indemnity (Elleman, 2001). This was followed by the Sino-French War in Annum (Vietnam) in 1884-85. During the war the French attacked Fuzhou in Southeast China, sank most of China's southern fleet and destroyed the Fuzhou Navy Yard. China was forced to cede the tributary status of Annum to France and later on Burma to Britain. This prompted Japan to make similarly aggressive moves to force China to relinquish Korea's tributary status in northeast China (Elleman, 2001).

In 1894-95 Japanese aggression sparked the Sino -Japanese war. The war ended with China's elite Beiyang naval fleet being completely destroyed. When Japan invaded Manchuria, there was little resistance from the Chinese army. In 1895, the Treaty of Shimonoseki awarded Taiwan, Penghu Islands and Liaodong Peninsular to Japan, together with 200 million ounce of silver as indemnity as well as fulfilling other numerous demands, including the loss of Korea as a Chinese tributary. The war also made clear to foreigners that the occupation of substantial parts of China was possible. Germany, Russia and Great Britain quickly demanded territorial concessions of their own. Russia annexed 154 million square kilometers of Chinese land, equivalent to $1 / 5$ of the Australian landmass. These areas have never been returned to China (Xue \& Luan, 2006) and have caused deep resentment for generations of Chinese. The later conflicts on the borders between China and the Soviet Union had much to do with this part of their history.

The defeat by Japan awakened Chinese out of their four thousand years of relative isolation. The Chinese emperor Guanxu developed an ambitious reform plan, aiming to transform the Chinese political landscape, education, economic system and military forces. Although the reform only lasted 103 days the impact on the Chinese military force lived on. The Qing Court this time concentrated the modernisation more on the army because of the land based foreign invasions, especially by the Japanese (Ni, 2008). A "New Army" was created. There was a 10 year plan to create 36 divisions with total troops numbering half a million. The reform also sought to build infrastructure to produce China's own arsenals. By 1910 China was producing mountain guns, ammunition, rifles and machines guns. Rebuilding of the navy was also implemented with soldiers sent to England for training (Fung, 1980)

By the turn of the $20^{\text {th }}$ century, anti foreign sentiment in China had grown dramatically due to the humiliating treaties and loss of large parcels of land areas. In 1900 the Boxers rebelled against the foreigners. Although it was put down by the collective efforts of eight nations - United Kingdom, France, Germany, Italy, Portugal, Japan, Russia, United States and Austria-Hungary - over $\$ 333$ million in indemnities and other compensations were paid to these countries, the anger of Chinese people toward foreign power dominance and bullying has never ceased to exist. Generations of young educated Chinese have vowed to respond to this humiliating chapter via building a strong China. This part of Chinese history is taught in all primary and secondary schools as well as universities throughout the modern era of China, currently as a compulsory subject (Liu, 2007). It has become an important motivation for creating a powerful military force. Further, the Boxers' faith in magic and martial arts, their belief that they were bullet proof proved to be no match for Western military technology 
and strategies. Thus this led to an on-going twentieth century trend of modernizing China's military forces along Western lines. (Elleman, 2001)

In the 1920's there was continued occupation and control in Northern China by the Soviet Union and Japan. In 1929 the Chinese Nationalist army was defeated by the Soviet Union when trying to regain control over the Chinese Eastern Railway (Elleman, 2001). In 1931 Japan gained control over Manchuria and in 1937 started an eight year war and occupation of China, concluding with the Japanese defeat by the allies in 1945. The wars cost China dearly in human lives and wealth. It is estimated by the Chinese that approximately 35 million people were killed or wounded during the war. Property losses and the expenses of the war were estimated at US\$100 billion (Wu, 2005). Chinese people largely blame the weakness of their military for the enduring conflicts and tremendous suffering of the nation.

\section{The Third Modernisation of China's Military in the Face of International Threats}

After the communist took over China in 1949, the first war China engaged in was the Korean War between 1950 and 1953. In June 1950, North Korea invaded the South. American led UN forces came to the South's rescue. In October, UN troops occupied the capital of North Korea, Pyongyang, and continued to push northward towards the Yalu River that separates China and Korea. Communist China was barely one year old and did not want to engage in another war. However, the American led UN troops were too threatening to be ignored. China launched a surprise attack with the 260,000 Chinese People's Volunteers crossing the border on the $19^{\text {th }}$ October $1950(\mathrm{Ni}, 2008)$. Although the Chinese troops successfully pushed the UN and South Korean troops back to the 38th parallel, they suffered very heavy casualties - between 450,000 and 1 million men, including Mao's son in the three year Korean War (Spence, 1990; Spurr, 1988). This led to the third major military reform in modern Chinese history.

Mao's People's Liberation Army (PLA) successfully created a mobile army, investing heavily in artillery, tanks and advanced Soviet Union aircraft. These reforms continued throughout the 1950's. China had sought support from the Soviet Union from the beginning of the new 1949 government and was provided with $\$ 300$ million in credits and thousands of military and industry advisors in this period (Elleman, 2001).

The size of the PLA was reduced from 5 million to 2.5 million, but equipped with modern rifles, mortars and artillery. Structurally, the original six military bureaus were divided into thirteen regional commands. Modern military academies were opened to train a new generation of officers on how to use Western tactics to conduct modern warfare (Ni, 2008).

The military budget was also increased significantly from 2.8 billion in 1950 to 5.5 billion in 1957, averaging between 20 to $40 \%$ of the entire government budget (Spence, 1990). In the early 1960s China was able to produce its own MiG $-17 \mathrm{~s}$, MiG-19s as well as T-54 tanks and naval patrol boats (Joffe, 1987). The third military modernisation was a clear success and had an enormous impact on the effectiveness of the PLA.

This modernisation provided China with the upper hand in the 1962 Sino-Indian Border War. In the context of India's granting sanctuary to the Tibetan spiritual leader, the Dalai Lama in 1959, there had been small border clashes and later on escalated into a full scale border war. The disputed areas were around 40,000 square miles. The border boundary lines had been drawn in 1842 and 1914. China claimed these boundaries were the result of unequal 
treaties during the British imperial era (Hoffmann, 1990). China had been forced to sign the treaties under military defeat and coercion to settle the borders which ceded the land to India, at the time a British colony. China believed it deserved to regain the land that belonged to them. However, India and the Western world thought that the borders were settled in 1914 and China was on a military expansion mission (Patel, 1963). This war ended with India's defeat.

In 1959 China's relationship with Soviet Union went sour. China had to repay all the aid provided by the Soviet Union. Russian advisors, engineers, technical staff, teachers and professors who were in China to help build Chinese industry, including military production, were all withdrawn. China had to become self reliant in order to continue the modernisation of its military. In June 1964, after nearly 10 years of research, China successfully tested its first nuclear bomb and joined the world nuclear club (Ni, 2008). The Chinese people were extremely excited and proud of this achievement. Importantly, in light of the unfriendly relationship with the Soviet Union and enemy status designated to the American allies, the bomb gave Chinese people a sense of security.

However, in 1966 Mao started the now infamous Cultural Revolution which lasted for 10 years. This Revolution brought the nation to a standstill in all aspects of life. Schools and universities were closed for nearly three years, factories, especially military factories, stopped production. Military goods were robbed or destroyed during some of the armed struggles. China was engaging in a nationwide self-destruction. All communication with the outside world ceased. Anyone who dared to do so would be sent to jail as a foreign spy. China was completely isolated from global activities at a time when globalisation was gaining a new momentum around the world. The outcomes of the 10 year Cultural Revolution were devastating. A generation of Chinese lost their opportunities for education and decent employment in urban areas. The Chinese economy fell into serious decline. People's standard of living was reduced to survival mode. Rations were applied for essential goods including grain, cooking oil, meat, nuts and even soap. The modernisation of the Chinese military was halted while the rest of the world was moving forward at a rapid pace.

\section{The Fourth Modernisation of China's Military in the Context of A Booming Economy Whilst Retaining Internal Unification}

The Cultural Revolution set China back at least 20 years through the destruction of people, education, facilities and national infrastructure. In 1978, just after the Cultural Revolution, Deng Xiaoping, then the paramount leader, emerged from the political wildness. He initiated badly needed economic reforms and implemented an Open Door policy to reconnect China with the rest of the world. Chinese leaders sensed the urgency to achieve the Four Modernisations that were announced in 1965 by the former Premier Zhou Enlai, a highly respected Chinese leader. However, amongst the Four Modernisations the military modernisation was the lowest priority as China had a pressing need to reform its economic system to save nation from the brink of economic collapse.

Since 1978, China's economic reforms have brought the country unexpected prosperity via 30 years of consecutive GDP growth of more than $9 \%$ a year. China embraced globalisation by opening its markets to the world in return for trade exports and foreign investments in China. The modernisation of agriculture, industry, science and technology has made remarkable progress during this period. However, the modernisation of the Chinese military 
was a lower priority given the need to create a strong economic foundation. In addition, a relatively less hostile global political environment also reduced the urgency for military modernisation. Relationships with the USA, Japan and the Western world were normalized and even relations with the Soviet Union (now Russia) were much improved.

However, in early 1991, Chinese leaders were stunned by the shock and awe of the American and its allies' military power during the First Gulf War. The surgical bombing and cruise missile attacks destroyed Iraqi air defences while electromagnetic warfare attacked Iraqi command and control networks. The First Gulf War was a walkover by the West against Iraq and revealed that Western warfare had made a quantum leap into a new era (Shambaugh, 2002). This war made the Chinese PLA and Communist Party leaders realise how far they had been left behind. In the 1980s, the PLA was preparing for "people's war under modern conditions" initially, then for "limited war". However, nothing prepared them for the shock of modern warfare exhibited by US forces and its allies. In the context of rapid modernisation of global warfare Beijing started a series of initiatives to truly modernize the Chinese military. Military strategy was revised focusing on high technology warfare, enhanced quality and effectiveness of the force (Shambaugh, 2002).

If the Gulf War opened the eyes of Chinese military leaders, then the 'Taiwan Crisis' of 1995 struck at the heart of the nation. In that year, Li Denghui, the president of Taiwan, was allowed to visit the USA. China was alarmed by the granting of a visa for the visit and concerned about the support given by the Americans to Li who harbored pro-Taiwan independence sentiments and was therefore a threat to stability of the region (Fisher, 2008). This was understandable in the context of the humiliating history in which China lost considerable parts of its land and tributary areas: China would strongly resist any more loss of its territory regardless of the circumstances. Taiwan has always been considered part of China. Even the Taiwanese government under the leadership of Chiang Kai-shek and his son had always had the mission to regain the mainland, in other words unification, but under the Nationalist leadership. China psychologically could not afford an independent Taiwan in the modern world and deeply believes it would be a loss of sovereignty (Zhang, J. 2009). Should that happen, it would be a repeat of the humiliating history. Too much national interest, in particular the nation's self-esteem, would be at stake. In response, China conducted military exercises initially in the mainland areas opposite Taiwan from July to November in 1995. In March 1996, the PLA fired M-9 missiles into the Taiwan Strait within miles of several harbors in Taiwan. America's response to this aggression was to display its biggest military might in Asia since the Vietnam War. President Clinton ordered ships including the USS Nimitz into the Taiwan Strait, the first transit by a U.S. warship in the Taiwan Strait since 1976, a clear signal by the U.S. that it was willing and ready to defend Taiwan in the face of PLA military action (Ling, Hwang, \& Chen, 2010).

The Taiwan Strait crisis identified the urgency for a rapid improvement in the Chinese military. The leaders decided to accelerate its military modernisation. In 1996 Chinese Premier Li Peng visited Moscow and ordered a Sovremenny Class Missile Destroyer. China subsequently ordered modern attack submarines (Kilo Class) and warplanes (Su-30MKK2) to counter the U.S. Navy's CVBG (Gill, 2007). A new doctrine emerged, "fighting a limited war under high-tech conditions"(Ji, 2004).

Since 1991 the PLA has undertaken many reforms. These include a reduction in the overall military size to 2.3 million combatants, increasing education levels, professionalising the force and developing smaller, more mobile units. Beijing has also placed emphasis on 
a Western style of military training. Special operation forces have been created in each of China's seven military regions (Blasko, 2006). The vision for China's ground force is to transform a continental military requiring a large ground force for in-depth defence to a smaller, more flexible, highly trained and well-equipped ground force with rapid reaction units (Crane, Cliff, Medeiros, Mulvenon, \& Overholt, 2005).

With regard to military equipment, Sloan (2008) identified that China continued to produce battle tanks such as the new T99, medium weight armored vehicles similar to America's Stryker, amphibious tank landing ships and so on. China is also developing self-propelled artillery and howitzers and precision guided artillery such as the A-100 and WS-2 multiple rocket launcher. China has developed fighter aircraft for more precision in air strike capability and possesses precision short-range ballistic missiles and a medium range (approximately 2,500 kilometers) ballistic missile - the Don Fang 21. Satellite guided technology has been used. In 2006 a concept for a supersonic, unmanned stealth combat aerial vehicle with primary air-to-air mission was unveiled (Sloan, 2008).

However, China's technology in military equipment production is limited. To compensate for this, in 2001 China signed a twenty year treaty with Russia for "friendship and cooperation" and imports a large mount Russian-built military devices such as Mi-17 troop lift helicopters, heavy transporters, air-cushion landing crafts, Kilo-class diesel electric submarines and Sovremenny II-class guided missile destroyers (Sloan, 2008). Since the beginning of the 1990's it is estimated that Moscow's defence sales to China averaged \$1 billion a year, increasing to $\$ 2$ billion a year from 1999. It is thought that China's main objective is to obtain a license and technology transfer for domestic production. However, Russia's assistance to China is restricted to defensive capabilities and exempts advanced technology (Rangsimaporn, 2006).

With the modernisation activities, China's military spending has been increased significantly. According to Fisher (2008), between 2001 and 2007 China's defence budget increased 258 percent. During the same period US military spending went up 83 percent. The fast growth in Chinese military expenditure has become a concern to many in the West. However, if the spending increase is put into perspective, it may not be that alarming. It is common knowledge that China started from a much lower base. Even with the highest US Defence Intelligence Agency (DIA) estimate, China's military spending in 2007 was between $\$ 85$ billion and $\$ 125$ billion. In contrast, the USA figure was $\$ 532$ billion. It is believed that China's total military expenditures are less than that of the US Navy budget ( $\$ 147$ billion) (Fravel, 2008).

China's military modernisation has alarmed some policy-makers and academics in the US and its Western allies, especially when a Chinese weather satellite was destroyed by a PLA direct-ascent anti-satellite missile. The successful test was a shock to the world. The much delayed acknowledgement of this event further added to the shock. As a result, China has been perceived to have global ambitions (Fisher, 2008). However, according to several research analysis of Chinese military modernisation, China's ability to project conventional military power beyond the Taiwan Strait and its periphery remains limited (Sloan, 2008; Foot, 2006; Smith \& Davies, 2010; Fravel, 2008). China has always maintained that its goal is defence based on "peaceful development", "non interference, no expansion" and "not seeking a super power position" (Liu \& Liu, 2009). The fact that China has only begun to acquire forces for maritime denial and regional force projection (Fravel, 2008) is indicative that its action is consistent with China's public announcement of its military modernisation 
intensions. The modernisation of China's air force over the past decade has focused on shortrange fighters, not long-range bombers. Similarly, the Chinese navy only possesses a modest ability to replenish ships required for long-distance patrols and is without any overseas naval bases (Fravel, 2008). Smith \& Davies (2010) believe that China is decades away from fielding a military to rival the US and it only has a modest capability to project military power far from its shores. It would appear much of China's military modernisation has been prepared for a potential conflict in relation to Taiwan.

\section{Making Sense of the Motivations for China's Military Modernisation}

Globalisation is viewed as a process to broaden and deepen interactions and interdependence among societies throughout the world (Cohn, 2005). This process started from the early world trade and economic interconnections, and thrived in the $16^{\text {th }}$ century. The Western invasion and colonization of much of Asia during the $18^{\text {th }}$ and $19^{\text {th }}$ centuries established a new mechanism for global interconnection (Holton, 1998). China is one of the major civilisations of the world with 5000 years of history. For a large part of its civilisation history, China has proudly claimed itself as a rich Middle Kingdom that led the world in many aspects such as agriculture, medicine, culture, philosophy, early science and technology. However, the globalisation force between 1840 and 1949 did not bring pride and dignity to the Chinese people. The series of Western invasions and semi-colonization caused huge financial and land losses and deep psychological scaring to the nation and its people. Humiliation and shame to the Chinese people has been intense.

Chinese culture is based on Confucianism which advocates dignity and self-esteem. For individuals, Confucius promoted the 'perfect man'. For society he focused on the collective good, social harmony, sacrifice and social hierarchy. There is a tendency for Chinese to seek perfectionism and to conform. People are very conscious of self-esteem. The well known 'face' issue in China is a reflection of the importance of Chinese self-esteem. It has also been a driving force for Chinese to work hard and achieve perfection.

Since the late Qing period, foreign invasions and consequent humiliations, economic crisis and collapse of the nation became an unbearable reality to many Chinese. The self-esteem of many individuals and the nation were in crisis. The extraordinary negative feeling in China toward this part of history can be attributed to a highly collective Chinese culture. In a collective culture, the nature of the self is fluid, embedded, interdependent, situated and particularistic (Heine, 2001; Kim, Triandis, Kagitcibasi, Choi, \& Yoon, 1994). Their selfesteem is more likely to be interdependent (Sinha, Willson \& Warson, 2000). When China as a nation was in crisis, many individuals' self-esteem, which was closely linked to and partially dependent on the prestige of the nation, was also badly damaged. To maintain a feeling of self-worth and control, nationalism was on the rise amongst many Chinese, especially the educated (Jiang, in press). It is in this historical and cultural context that China staged four attempts of military modernisation. The motivation for the modernisation of the Chinese military has always been high and predominantly based on nationalism and a need for self-esteem.

The first two modernisation attempts aimed to save the nation from being divided up by Western powers. However, China's finances were depleted by many years of internal conflicts, foreign invasions and paying large indemnities. The modernisation movement made some progress yet not enough to defend the country. Foreign invasions, wars and conflicts contin- 
ued. Globalisation for the Chinese during those periods was much more bitter than sweet experiences.

The third modernisation attempt was motivated by the Korean War with a realisation of the potential vulnerable Chinese position in the face of American led UN forces as enemies. The threat to China was again quite real. To avoid history repeating itself, Communist China had no choice but to modernise its military. International support from the Soviet Union was the key for this modernisation. China gained much more success in its military modernisation as a result of both global threats and support from the Soviet Union.

The last attempt of modernisation has also been motivated by perceived international threats to China - the US military might and the Taiwanese independence movement. Independence to the West is a positive term that derived from individualist cultures. It indicates self autonomy and freedom. However, to collectivism orientated mainland Chinese, it is very negative phrase signifying separation and loss that remind them of the pain of contemporary Chinese history. The West's view is that China's military build up has progressed at an alarming rate and consequently feels threatened. Western feelings of insecurity are accentuated due to China's ever expanding strong economy which can finance the current modernisation. However, it is estimated that China's military spending has remained constant at approximately 8 percent over the past 15 years and is not favouring defence spending over other government priorities such as education (Fravel, 2008). Nevertheless, with the growth of GDP and government income and expenditure each year, the growing economy becomes the engine of military modernisation. This was not the case in the earlier three modernisation attempts. The core objective of the last modernisation is to protect the unity of China. It would appear that China will stop Taiwan's independence at all cost, not for the sake economic benefit but for national unity and national self-esteem. China is determined not to have a repeat of history.

\section{Challenges in China's Military Modernisation}

Although China's military modernisation has transformed the landscape of PLA, many challenges still exist. The majority of PLA soldiers come from rural China where basic education is inadequate. China has invested heavily in its military education system, raised salaries, tightened recruitment standards and introduced new measures to attract and retain technology savvy talent for the military (Sloan, 2008). However, it will take considerable time to make the changes required to meet the challenges in a high-tech war, given university educated youth in China is only a very small percentage of the population when compared to the USA and other Western countries. Most educated young Chinese do not see a career in the military as their preferred future.

Currently China has only limited capability to produce advanced military equipment. Russia and the US see China as a rival: they do not sell nor allow their allies to sell advanced weaponries to China. Perhaps due to an education system that does not encourage innovation and independent thinking, the Chinese have been more competent in copying, but less capable in innovation.

Further, the West has long been concerned about transparency with regard to China's military including its budget, weaponry, equipment, training and so on. China has had some exchanges with the US military allowing greater PLA access to the US side. During these exchanges China has learned more about US capabilities without much reciprocation. This 
has caused considerable disappointment in America and resulted in reduced US and PLA exchanges. It is also one of the main reasons for the tight control in transferring US and Russian military technology to China (Fisher, 2008). However, according to Chinese culture, transparency is not recommended, especially in warfare. Sun $\mathrm{Zi}$, the ancient Chinese military strategist, promoted secrecy as a "force multiplier" (Fisher, 2008). In 1989 Deng Xiaoping also outlined his key principles for foreign policy, including "observe developments... hide our capacities, bide our time, remain free of ambition and never claim leadership" (Zhang, Y. 2009, p.74). However, with the West's growing concern regarding China's military modernisation, a lack of transparency would only confirm worst-case assumptions about China's ambition (Fravel, 2008). Nevertheless, China will not increase transparency anytime soon because of the Taiwan issue. It will not reveal the real capabilities of Chinese military in relation to the mission of China's unification of Taiwan.

\section{Conclusion}

Under the impact of globalisation, China has experienced four attempts at military modernisation. Each attempt was motivated by threats to China and the desire to defend its national interest and self-esteem. Globalisation has also brought great benefits to China enabling the country to embark on the most recent ambitious military modernisation. However, it should be acknowledged that consistent with the three previous attempts, this modernisation is more oriented to defending national interests and self-esteem. Although the rapid military transformation has alarmed or threatened the West, in reality China's intentions are more about self-defence and nullifying independence movements in China, in particular Taiwan, and has little to do with expansion of territory. China is particularly concerned about a possible domino effect should Taiwan gain independence given China has 56 ethnic groups, some of whom may seek real autonomy or independence in the future. This understanding of Chinese history, culture and mores may serve as a buffer to alleviate Western anxiety and thus avoid overreaction to Chinese military activities.

\section{References}

Blasko, D. J. (2006). The Chinese army today. London: Routledge.

Cohn, T. H. (2005). Global political economy: Theory and practice. New York: Longman.

Crane, K. Cliff, R. Medeiros, E. Mulvenon, J. \& Overholt, W. (2005). Modernizing China's military: Opportunities and constrains. Santa Monica: RAND Corporation.

Elleman, B. A. (2001). Modern Chinese Warfare, 1795-1989. Hoboken: Routledge.

Fay, P. W. (1975). The Opium War 1840-1842. Chapel Hill: University of North Carolina Press.

Fisher, R. D. (2008), ed. China's Military Modernization: Building for Regional and Global Reach Santa Barbara: Praeger Security International General Interest.

Foot, R. (2006). Chinese strategies in a US-hegemonic global order: Accommodating and hedging. International Affairs 82(1), 77-94

Fravel, T. (2008). China's search for military power. The Washington Quarterly. 31(1), 125-141.

Friedman, N. (2009), U.S. Naval Institute Proceedings. 135(11), 90-91

Fung, E.S.K. (1980). The Military dimension of the Chinese revolution: The New Army and its role in the revolution of 1911. Vancouver: University of British Columbia Press.

Gill, B. (2007). Rising Star: China 's New Security Diplomacy. Washington: Brookings Institution Press. 
Heine, S. J. (2001) Self as cultural product: An examination of East Asian and North American selves. Journal of Personality, T69, 881-906.

Hoffmann, S. A (1990). India and China crisis. Berkeley: University of California Press.

Holton, R. J. (1998) Globalisation and the Nation-State. London: Macmillan Press.

Ji, Y. (2004), "Learning and catching up: China's revolution in military affairs initiative," in E. O. Goldman and T. G. Mahnken (Eds). The information revolution in military affairs. New York: Palgrave Macmillan. 106

Jiang, H. (2009). China's foreign affairs under the military 'soft power'. 轮军事软实力视野下的中 国军事外交。Gansu Social Sciences. 2, 238-241.

Jiang, X. (In Press). Making Sense of Changes in Education, Social Justice and Equity for Women in China. In D. A. Harley, T. A. Savage \& E. L. Brown, (Eds). International Advances in Education: Global Initiatives for Equity and Social Justice, Volume 3, Gender and Sexuality. Charlotte, NC: Information Age Publishing

Joffe, E. (1987). The Chinese Army after Mao. London: Weidenfeld \& Nicholson.

Kim, U., Triandis, H. C., Kagitcibasi, C. Choi, S. \& Yoon, G. (1994). Introduction. In U. Kim, H. C. Triandis, C. Kagitcibasi, S. Choi, \& G. Yoon, Individualism and collectivism. (pp. 1-18). Thousand Oaks: Sage.

Ling, L.H.M., Hwang, C. \& Chen, B. (2010). Subaltern straits: 'exit', 'voice', and 'loyalty' in the United States-China-Taiwan relations. International Relations of the Asia-Pacific. 10(1). 33-59

Liu, C. \& Liu, Y. (2009). The basic experiences of 60 years of Chinese national defense and military development of the new China. 新中国60年国防和军队建设的基本经验。National Defense. $10,7-13$

Liu, C. (2007). Opium Wars and the research of Chinese modern history: based on the Chinese history textbook in the period of late Qing Dynasty and Republic of China. 鸦片战争与中国近代 史研究- 以清末民国时期中国历史教科书为中心。Academic Monthly. 39(6) 146-153

Lorge, P. A. (2008). The Asian military revolution: From gunpowder to the bomb. Leiden: Cambridge University Press.

Ni, L. (2008). Reflection on modernisation of Chinese military in the 20 th century. 二十世纪中国 军事现代化的反思. Retrieved on $14^{\text {th }}$ July from the Online Chinese Thesis: http://www.zclw.net/article/sort024/sort025/info-26505_5.html

Petal, I. (1963). The Border problem. In V.B. Karnik, (Ed.). China invades India. Bombay: Allied Publishers, 185-191.

Rangsimaporn, P. (2006). Russia's debate on military-technological cooperation with China: From Yeltsin to Putin. Asian Survey. 46(3), 477-495

Shambaugh, D. (2002). Modernizing China's military: progress, problem, and prospects. Berkeley: University of California Press.

Sinha, B. K.; Willson, L. R. \& Warson, D. C. (2000). Stress and coping among students in India and Canada. Journal of Behavioural Sciences, 32(4), 218-225.

Sloan, E. (2008). Military transformation and modern warfare: A reference handbook. Westport. Greenwood Publishing Group

Smith, S. \& Davies, A. (2010) China's strategy is denial of access. The Australian. May 29-30, Defence, 5

Spence, J. D. (1990). The search for modern China. New York: W.W. Norton \& Co.

Spurr, R. (1988). Enter the Dragon: China's undeclared war against the U.S. in Korea 1950-1951. New York: Newmarket Press.

Tan, P. (2009). The recruitment of talents and China's early modernisation of military force. 人才引 进与中国早期军事现代化进程。Heilongjiang History Research. 207(14), 58-59

Wu, C. (2005). Remember role in ending fascist war. China Daily $15^{\text {th }}$ August, 2005 Retrieved on $15^{\text {th }}$ July, 2010 from http://www.chinadaily.com.cn/english/doc/2005-08/15/content_468908.htm 
Xue, X. \& Luan, J. (2006). History and reality of Sino-Russia relations. 中俄关系的历史与现实--从 三次结盟到《睦邻友好合作条约》Journal of Sino-Russia Relationships Research, 4, Retrieved on $15^{\text {th }}$ July, 2010 from http://jds.cass.cn/Article/20060414151722.asp

Zarrow, P. (2005). China in war and revolution 1895-1949. Hoboken: RoutledgeCurson.

Zhang, J. (2009). Major achievements of new China in modernisation of national defence and the armed forces and the historical experience. Journal of Research on Chinese Communist Party History. 10, 85-92

Zhang, Y. (2009). The innovation and development to military guiding theory by Deng Xiaoping. 论 邓小平对党的军事指导理论的创新和发展。Journal of China Executive Leadership Academy Jinggangshan. 2(1) 72-78.

\section{About the Authors}

Dr. Xiaoli Jiang

Dr. Xiaoli Jiang is a senior lecturer and program coordinator of the Bachelor of Arts (International Studies) at the University of Ballarat. She has diverse research interests in the areas of Chinese culture, education and self-esteem; Asian migration and well-being of migrants; cross-culture self-esteem and children's self-esteem. In 2009, Dr. Jiang won a prestigious Australian Learning and Teaching Council Citation for her outstanding contributions to student learning.

Yihong Gong

Baiyun University, China 


\section{THE \\ GLOBAL STUDIES JOURNAL}

\section{EDITORS}

Jan Nederveen Pieterse, University of California, Santa Barbara, USA.

Bill Cope, University of Illinois, Urbana-Champaign, USA.

\section{EDITORIAL ADVISORY BOARD}

Jin-Ho Jang, Institute for Social Development and Policy Research,

Seoul National University, Seoul, South Korea.

Habibul Haque Khondker, Zayed University, Abu Dhabi, United Arab Emirates.

lain Donald MacPherson, University of Calgary, Calgary, Canada.

Bhikhu Parekh, University of Hull, Hull, UK; Member, House of Lords, UK.

Thomas Pogge, Columbia University, New York, USA.

Timothy Shaw, University of the West Indies, St. Augustine, Trinidad.

Manfred B. Steger, RMIT University, Melbourne, Australia.

Gustavo Lins Ribeiro, Instituto de Ciências Sociais, Universidade de Brasília, Brasília, Brazil.

Fazal Rizvi, University of Illinois, Urbana-Champaign, USA.

Please visit the Journal website at http://www.GlobalStudiesJournal.com for further information about the Journal or to subscribe. 


\section{THE UNIVERSITY PRESS JOURNALS}

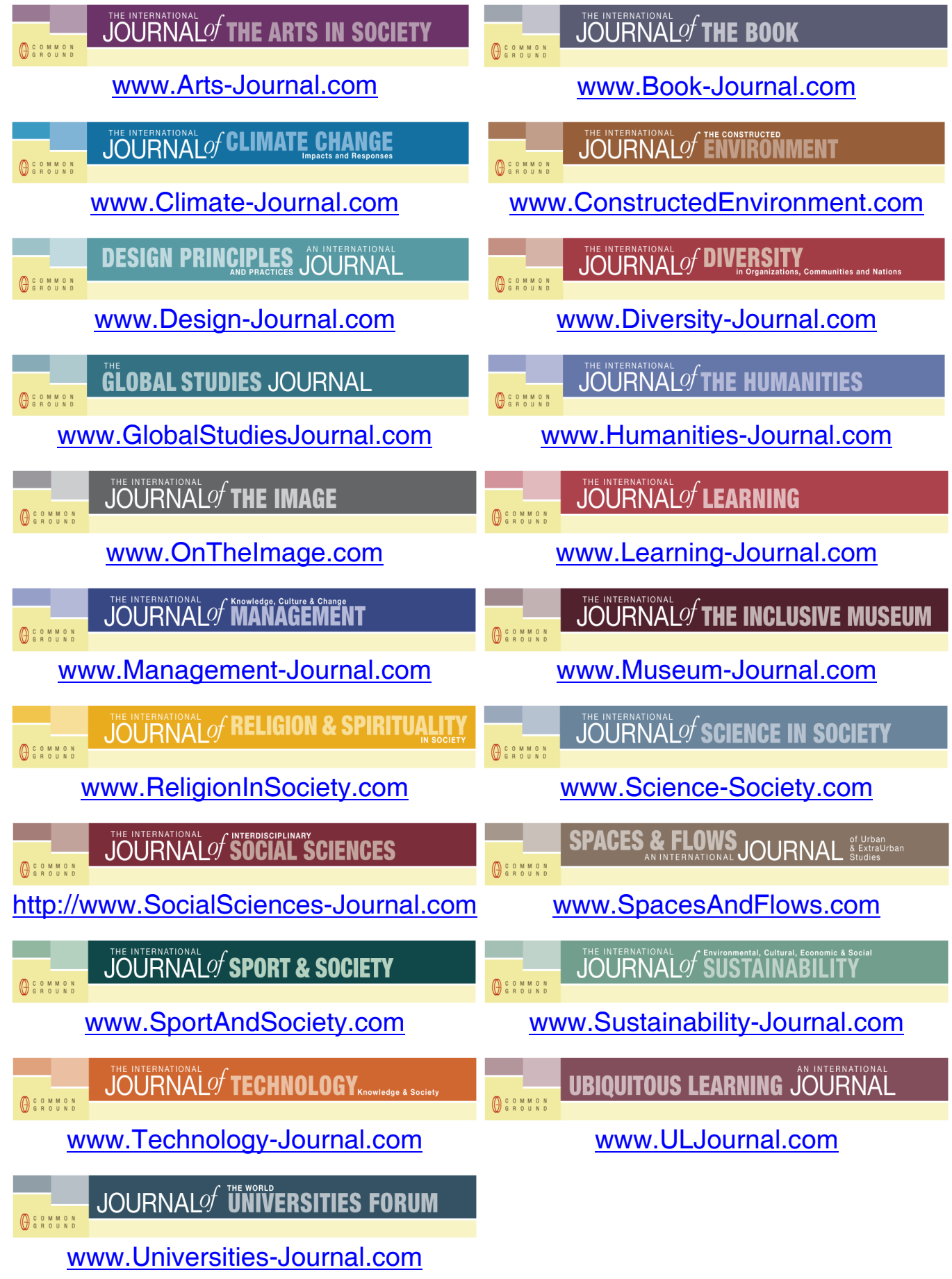

FOR SUBSCRIPTION INFORMATION, PLEASE CONTACT subscriptions@commongroundpublishing.com 